Acta Zoológica Mexicana (n.s.) 23(2): 1-9 (2007)

\title{
PAPILIONIDAE AND PIERIDAE BUTTERFLIES (LEPIDOPTERA, PAPILIONOIDEA) OF THE STATE OF GUANAJUATO, MEXICO
}

\author{
Alexander V. KiR'yanov* y Manuel A. Balcázar-LaRA** \\ *Centro de Investigaciones en Óptica, \\ Loma del Bosque, No. 115, Col. Lomas del Campestre, León 37150, Guanajuato, MÉXICO \\ **Facultad de Ciencias Biológicas y Agropecuarias, Universidad de Colima, \\ Km 40 Autopista Colima-Manzanillo, Tecomán 28100, Colima, MÉXICO \\ kiryanov@cio.mx mabl@cgic.ucol.mx
}

\begin{abstract}
RESUMEN
Presentamos, por primera vez, una lista anotada de las familias Papilionidae y Pieridae (Lepidoptera: Papilionoidea) para el estado de Guanajuato. Esta lista es el resultado de muestreos sistemáticos de estos taxones en un conjunto de localidades del estado (principalmente en las cercanías de León y la Ciudad de Guanajuato) durante 1998-2004, así como de especímenes depositados en la Colección Nacional de Insectos. Se registran 12 de Papilionidae y 27 especies de Pieridae, de las cuales 4 y 15 respectivamente son nuevos registros para el estado. Por lo anterior 30\% de las especies de Papilionidae y 50\% Pieridae constituyen nuevos registros estatales. Se presentan algunas observaciones de la ecología y distribución de los taxones encontrados.

Palabras Clave: Biodiversidad, distribución, fauna, Guanajuato, lista anotada, mariposas, México, riqueza de especies.
\end{abstract}

\begin{abstract}
An annotated list of butterflies of the families of Papilionidae and Pieridae (Lepidoptera: Papilionoidea) of the state of Guanajuato, Mexico, is presented for the first time. The list is the result of systematic monitoring of these taxa in a few localities of the state (mainly, in the vicinities of León and Guanajuato City) during 1998-2004, as well as from specimens at the Mexican National Collection of Insects. We report 12 species of Papilionidae (4 new records for the state), and 27 species of Pieridae (15 first records for Guanajuato). Therefore, at least about $30 \%$ and $50 \%$ of species of, respectively, Papilionidae and Pieridae, are registered as new state records. Some distributional and ecological observations for the butterflies are addressed as well.
\end{abstract}

Key Words: Biodiversity, checklist, distribution, Guanajuato, Mexico, Papilionidae, species account.

\section{INTRODUCTION}

The state of Guanajuato is located in Central Mexico, in the southern high plateau. Its northern half is occupied by a group of mountain ranges (sierras): Guanajuato, Gorda, 
de la Media Luna, and Comanjilla, and the southern part is occupied by the Transvolcanic Axle. Between these mountainous formations there is a fertile plain called Bajío, in the Lerma River Basin. Although there are 13 different types of vegetation within the state, $50 \%$ of the territory is used for agricultural purposes, and another $13 \%$ has been altered or lacks natural vegetation. The vertebrate fauna is poorly known and most studies date back to the 19th century. Besides, the state has only one natural area proposed for protection: Sierra de Santa Rosa (Flores \& Gerez 1994). The National Commission for Biodiversity (CONABIO) has identified three priority terrestrial areas for study within Guanajuato: Sierras Santa Bárbara - Santa Rosa, Hoya Rincón de Parangueo, and Cerro Zamorano (Arriaga et al. 1997). Most of the state is located in the Nearctic region, Mexican Plateau province, while the southernmost part lies within the Neotropical region in the Transmexican Volcanic Belt province (Morrone 2001).

The Papilionidae and Pieridae fauna of Mexico has been investigated to-date in an uneven fashion. Comprehensive faunistic information is available in the literature for only a few Mexican states or large areas: Chiapas (de la Maza \& de la Maza 1993), Guerrero (Vargas et al. 1991), Oaxaca (Luis et al. 1991), Nuevo León (Beutelspacher 1983a), Baja California peninsula (Brown et al. 1992), and the Valle de México (Beutelspacher 1980; Luis \& Llorente 1990). While most of the observation and collecting has been done in very species-rich localities in Chiapas (Beutelspacher 1983b, Díaz 1975, 1985a, de la Maza \& de la Maza 1985b), Oaxaca, Veracruz (Beutelspacher 1975, de la Maza \& de la Maza 1978, 1979, Llorente et al. 1986), Guerrero (de la Maza et al. 1982, Vargas et al. 1991), San Luis Potosí (de la Maza 1980, de la Maza \& de la Maza 1981, de la Maza \& de la Maza 1978), and Estado de Morelos (de la Maza et al. 1995, de la Maza 1975), other states clearly have fewer areas studied. Most of the literature is quite fragmental even for the best known states (i. e. Balcázar 1993, Brown 1943, 1944, Clench 1963, 1968, González-Cota 1978; Guzmán 1976). The information for both families has been summarized by Llorente et al. (1998).

Guanajuato ranks among the seven least collected states in Mexico, with less than 200 records for Papilionidae and Pieridae according to data both from collections and literature (Llorente et al. 1998). Due to its position, this state is crucial to help us understand the biogeography of several groups of butterflies especially those that are found in the Pacific slope and the high Plateau. On the other hand, it is worth noting that the state of Guanajuato is one of the most industrial Mexican states and its natural vegetation is highly altered, so butterflies can be used as indicator groups for monitoring environmental issues and the state of conservation in natural areas, especially those located near industrial cites (Korolew \& Kiryanov 1998). 


\section{MATERIAL AND METHODS}

This study is limited to a checklist for the Papilionidae and Pieridae of Guanajuato, concentrating attention on the species that are characteristic for most of the Bajío. The main localities where the butterflies were collected are León (the largest city in Guanajuato) and its vicinities (Sierra de Comanja) and Guanajuato City with its bufas as well as a few more geographical localities - the Valle de Santiago, Valle de la Piedad, and some others. Thus, the central (the Bajío itself) and Southwest parts of Guanajuato were covered. This represents the most widespread and homogeneous landscapes.

All the specimens have been collected by one of the authors (A.V. K.) during the 1998 - 2004 using standar collecting methods. Additional data were obtained (by M.B.L.) from the National Collection of Insects (CNIN, Instituto de Biología, UNAM).

\section{RESULTS}

New records for Guanajuato are marked with an asterisk (*); taxa cited in the literature but not collected by the authors are marked with a question mark (?).

\section{SPECIES LIST}

\section{PAPILIONIDAE}

1. Protographium epidaus fenochionis (Salvin \& Godman, 1868). A seasonal butterfly. The flight time is as of B. philenor, however few individuals appear also in April-May. It is most abundant on the Buffas near Guanajuato City. There are some individuals with intermediate characters between the three subspecies in the area.

2. Mimoides thymbraeus aconophos (Gray, [1853]). A rare species for Guanajuato; only a few localities near León have been recorded. It is found only in July-August.

3. Battus philenor philenor (Linnaeus, 1771). A common species for Guanajuato. It appears in the summer and earlier autumn months (July-September, one generation), prefers hilltops and flies above tree tops. The form without tails on hind-wing is more frequent.

4. Heraclides cresphontes (Cramer, 1777). An abundant species in all localities of the state, flying through the year, being most numerous in July-September.

5. *Heraclides ornythion (Boisduval, 1836). A new record for Guanajuato. Only one male was captured in the vicinities of Guanajuato City (July, 2003). However, a permanent status of this species in the state should be confirmed.

6. Heraclides rogeri pharnaces (Doubleday, 1846). The most frequent (even in urban landscapes) swallowtail butterfly in Guanajuato; it is found throughout the year.

7. Heraclides thoas autocles (Rothschild \& Jordan, 1906) *. A new record for Guanajuato. It is rarely found in the Southern part of the state (for instance, in Valle de Santiago). Also, one male has been 
Kir'yanov \& Balcazar-Lara: Butterflies of the State of Guanajuato

captured $30 \mathrm{~km}$ South from León (Comanja de Corona, Jalisco, August, 1999); but never in the near vicinities of León and Guanajuato. Meanwhile. It is evident to the authors that $H$. thoas is a permanent resident in Guanajuato.

8. Papilio polyxenes asterius Cramer, 1782. An abundant species, but it flies only in summer (JulyAugust). The male behavior resembles that for all other representatives of the "machaon group", i. e., the patrolling over hills or tree canopies in search for females and aggressive actions against competing males.

9. Pterourus garamas garamas (Geyer, [1829]). A common species for the state. At least, two generations per year (July-August and October-November). The ratio of sexes is highly skewed, males five times encountered more often than females. The behavior of P. garamas is different from other local swallowtails: These butterflies (especially females) prefer to fly around the tree canopies, frequently resting on leaves.

10. *Pterourus glaucus garcia (Rothschild \& Jordan, 1906). Only one record in the suburbs of León, near the border with Jalisco state on the road to Lagos de Moreno (June, 2002). Most probably, this butterfly is not a permanent species in Guanajuato, being a stray from the northern Mexican territories (Tyler et al., 1994).

11. Pterourus multicaudata (Kirby, 1884). An all-season butterfly in Guanajuato, being abundant in all localities, especially in the summer and autumn months.

12. *Pterourus pilumnus (Boisduval, 1836). Only two records (June, 1998 and July, 2001; the Bufas de Guanajuato). Never has been recorded in other localities of the state. A rare butterfly in Guanajuato.

\section{PIERIDAE}

1. (?) Lieinix nemesis nayaritensis Llorente, 1984. There is an old reference that addresses this species as to occur in Guanajuato (Lamas, 1979). This is based on a specimen kept at the Natural History Museum (BMNH, London) and collected by E. Dugès, which is labeled "Guanajuato". All the attempts to collect this butterfly during 1998 - 2004 were unsuccessful. Most probably, this species is not an actual inhabitant of the state.

2. Colias eurytheme Boisduval, 1852. An abundant species in Guanajuato in all natural stations. Only one very long generation per year, with the maximum number of imagoes flying from July to September. This species is not found during the winter months. All the forms of females (yellow, orange, and white) are present; males also show a huge variability in coloring and size. It has been recorded a mass flight of C. eurytheme in Valle de Santiago in August, 1999.

3. Zerene cesonia cesonia (Stoll, 1790). A common and frequent species in the state. A few ovelapping generations per year, with mass flight from July to August. In winter Z. cesonia is a rare species. Many forms of both males and females are found, but differences in forms are mostly seasonal (winter butterflies are paler).

4. *Anteos clorinde (Godart, [1824]). A few records during the 1998 - 2004 period (León and Sierra de Comanja), mainly in July and August. This species is regularly seen each year and therefore is not a stray in Guanajuato. Females are found more rarely than males.

5. Anteos maerula (Fabricius, 1775). A more common species than the previous one, which is also seasonal (July and August). The number of males is about 10 times higher than that of females. The butterfly inhabits all the studied localities of Guanajuato. 
6. *Phoebis agarithe agarithe (Boisduval, 1836). A rather abundant and all-season species, even though there were any records about its presence in Guanajuato.

7. * Phoebis argante argante (Fabricius, 1775). A rare species in the state, with only a few records during the period of study. A relative ratio of the records for this species and the previous one is about $1 / 20-$ the ratio is obtained by a statistical catch proceeded for both the species (hardly distinguishable in flight) within the period of a mass flight of $P$. agarithe (July to August). We may clearly conclude that $P$. argante, although rare indeed, is a native species (not a stray) in Guanajuato.

8. *Phoebis philea philea (Linnaeus, 1763). Also an uncommon species. There were about 20 records during the monitoring period, mainly in autumn (September-October). There are two forms of females as in other localities in Mexico: white (most frequent in Guanajuato) and orange.

9. *Rhabdodryas trite (Linnaeus, 1758). Only two males have been captured (September, 2001) in the northern suburbs of León. The permanent status of this species for Guanajuato needs to be confirmed.

10. Abaeis nicippe (Cramer, 1779). An abundant butterfly throughout the year. Two seasonal forms are found, while the winter form is rather rare.

11. *Pyrisitia lisa centralis (Herrich-Schäffer, 1865). A rare butterfly in the state. Only three specimens (2 males, 1 female) were captured during the period 1998-2004. This species is probably native to Guanajuato, but additional systematic studies are needed to confirm this.

12. *Pyrisitia nise nelphe (R. Felder, 1869). A frequent butterfly, more or less abundant in July to September, but a few butterflies can be found from January to March as well.

13. *Pyrisitia proterpia (Fabricius, 1775). An abundant species; a few generations during a year. As in case of $A$. nicippe, two seasonal forms are found.

14. Eurema daira eugenia (Wallengren, 1860). A common butterfly in Guanajuato, found in all seasons. Both females and males are variable in color (from snow-white to extensively dark-yellow, especially on the upper-side).

15. *Eurema mexicana mexicana (Boisduval, 1836). An abundant, but seasonal, species - it flies in great numbers in summer and autumn (one prolonged generation); during the winter (December-March) only a few butterflies are found.

16. *Eurema salome jamapa (Reakirt, 1866). A rare butterfly, only one couple was captured in Sierra de Comanja (March, 2004).

17. Nathalis iole Boisduval, 1836. An extremely abundant all-season species in all the localities. For instance, near Valle de Santiago, all damp ground was occupied by hundreds of these small butterflies "puddling". We note presence of the form of $N$. iole with large red spots at the corners of the hindwings (upper-side).

18. *Kricogonia lyside (Godart, 1819). Only one specimen, a male, was captured near Guanajuato City (August, 1999). Because of a high mobility of this species (Byers, 1971), this record was, without doubts, a stray; $K$. lyside is not likely to be a native species in Guanajuato.

19. *Hesperocharis costaricensis pasion (Reakirt, [1867]). A new record for Guanajuato. A study of the behavior of this butterfly in the vicinities of León has shown that it is a native species, because we 
Kir'yanov \& Balcazar-Lara: Butterflies of the State of Guanajuato

observed females laying eggs on food-plants many times. A seasonal species and apparently double brooded: first generation in February-March and the second in June-July. H. costaricensis pasion shows so-called "waves of life": In 1998 and 2003-2004, this species was abundant, while in other years only a few specimens were recorded.

20. Eucheira socialis socialis Westwood, 1834. This species is cited for the vicinities of Guanajuato City and Dolores Hidalgo (Llorente et al., 1998), but we never found it, despite all our efforts.

21. * Catasticta nimbice nimbice (Boisduval, 1836). A new record for Guanajuato, this species is abundant and an all-season butterfly. However, these butterflies clearly prefer places where water can be found all year long - i. e., along streams, lake shores, etc. Like H. costaricensis pasion, C. nimbice also show "waves of life" - in some years, it is a mass-flying butterfly (i. e., 2000, 2002-2004), while sometimes it becomes scarce (i.e., 1998-1999). It is very variable in size; in the winter dwarf individuals of less than two centimeters of wingspan can be found.

22. Melete lycimnia isandra (Boisduval, 1836). According to literature data, this species is found in Guanajuato. However, during our observations, M. lycimnia was captured only once - October, 2002 (in the streets of León).

23. Glutophrissa drusilla tenuis (Lamas, 1981). As E. socialis, this species has been recorded for Guanajuato (Llorente et al., 1998); it was collected only once in the vicinities of León (June, 2004).

24. Pieris rapae rapae (Linnaeus, 1758). This circumpolar species is a flier in the vicinities of main cities, and even in their streets; it is quite seasonal. We found this butterfly mainly in spring and winter. Its presence in Guanajuato (together with nymphalids like N. antiopa, V. atalanta, V. cardui) is an indication that this area is one of the furthest South geographical points, where the circumpolar flora and fauna reach.

25. *Pontia protodice (Boisduval \& LeConte, [1830]). A new a record for Guanajuato, being found mostly in the Northern Mexican states and the adjacent territories of the USA. It is found in Guanajuato twice per year - in spring (February-March) and autumn (September-October). A very variable species in size. P. protodice is a characteristic butterfly for cities, rather than for natural landscapes.

26. Leptophobia aripa elodia (Boisduval, 1836). An abundant, all-season species, which occupies many localities, but is more frequent in places with water sources (e.g. springs, ponds).

27. *Ascia monuste monuste (Linnaeus, 1764). A new record for Guanajuato. Only two records during the monitoring period - September, 2003. There are some doubts about resident status for this butterfly in the state.

\section{DISCUSSION}

Our list for the Papilionidae and Pieridae fauna of Guanajuato is the most comprehensive published to date (c. fr. Llorente et al., 1998). Four out of 12 papilionids reported here are new state records (Heraclides ornythion, H. thoas autocles, Pterourus glaucus garcia and P. pilumnus), and 14 of 27 pierids are new records for Guanajuato (Anteos clorinde, 
Phoebis a. agarithe, P. a. argante, P. p. philea, Rhabdodryas trite, Pyrisitia lisa centralis, P. nise nelphe, P. proterpia, Eurema m. mexicana, E. salome jamapa, Kricogonia lyside, Hesperocharis costaricensis pasion, Pontia protodice, Ascia m. monuste).

It is important to note that additional studies in localities at the periphery of the state, for instance, the areas adjacent to the states of San-Luis Potosí in the North, the state of Querétaro in the East, and the state of Jalisco in the South are in need of research for a more complete faunistic list.

\section{ACKNOWLEDGEMENTS}

The database for the butterfly collection at the National Insect Collection, Instituto de Biología, National University, Mexico was compiled thanks to CONABIO grant FB327/J083/96. We want to thank Alma Solis (SEL, Washington, D. C) and Andrew Burton (SQU, Oman) for their comments on the manuscript.

\section{REFERENCES}

Arriaga, L., Aguilar, C., Espinosa, D. \& Jiménez, R. 1997. Regionalización ecológica y biogeográfica de México. Taller desarrollado en la Comisión Nacional para el Conocimiento y uso de la Biodiversidad (CONABIO).

Balcázar-Lara, M. A. 1993. Butterflies of Pedernales, Michoacan, Mexico, with notes on seasonality and faunistic affinities (Lepidoptera: Papilionoidea and Hesperioidea). Tropical Lepidoptera 4: 93-105.

Beutelspacher, C. R. 1975. Notas sobre el Suborden Rhopalocera (Lepidoptera) de Las Minas, Veracruz. Revista de la Sociedad Mexicana de Lepidopterología 1: 11-20. - 1980. Mariposas diurnas del Valle de México. La Prensa Médica Mexicana, Mexico City. 1-134 p. . 1983a. La familia Pieridae (Lepidoptera) en el estado de Nuevo León, México. Anales del Instituto de Biología UNAM, Serie Zoología 53: 367-378. . 1983b. Mariposas diurnas de "El Chorreadero", Chiapas (Insecta: Lepidoptera). Anales del Instituto de Biología UNAM, Serie Zoología 53: 341-366.

Brown, F. M. 1943. Notes on Mexican butterflies I. Papilionidae. Journal of the New York Entomological Society 51: 161-178.

. 1944. Notes on Mexican butterflies II. Pieridae. Journal of the New York Entomological Society $52: 99-119$.

Brown, J. W., Real, H. G. \& Faulkner, D. K. 1992. Butterflies of Baja California: faunal survey, natural history, conservation biology. Lepidoptera Research Foundation, Beverley Hills. 1, i-v, 1-145 p.

Byers, G. W. 1971. A migration of Kricogonia castalia (Pieridae) in Northern Mexico. Journal of the Lepidopterists' Society 25: 124-125.

Clench, H. K. 1963. A collection of butterflies from Western Chihuahua, Mexico. Entomological News 26: 157-162. 
Kir'yanov \& Balcazar-Lara: Butterflies of the State of Guanajuato 22:227-231.

. 1968. Butterflies from Coahuila, Mexico. Journal of the Lepidopterists' Society

Díaz, A. 1975. Relato de un viaje al sureste de México. Revista de la Sociedad Mexicana de Lepidopterología 1: 23-24.

Flores, O. \& Gerez, P. 1994. Biodiversidad y conservación en México: vertebrados, vegetación y uso del suelo, $2^{\circ}$ ed. UNAM, México, D. F. 439 p.

González-Cota, L. 1978. Notas sobre la familia Papilionidae (Lepidoptera) en México Barranca de Patla, Pue., y alrededores. Boletín Informativo de la Sociedad Mexicana de Lepidopterología 4: 3-15.

Guzmán, P. 1976. Algunas observaciones sobre Lepidopteros de Chalma, Estado de México. Revista de la Sociedad Mexicana de Lepidopterología 2: 49-51.

Korolew, W.A. \& Kiryanov, A.V. 1998. Butterflies (Lepidoptera, Diurna) from the NaturalPark "AlaArcha" (Tien-Shan, Kirghizian mountains). Entomological News from Russia 1: 15-28.

de la Maza, J. \& de la Maza, R. 1985a. La fauna de mariposas de Boca del Cajul, Chiapas, México, (Rhopalocera). Parte II. Revista de la Sociedad Mexicana de Lepidopterología 10: 1-24.

- 1985b. La fauna de mariposas de Boca del Chajul, Chiapas, México, (Rhopalocera). Revista de la Sociedad Mexicana de Lepidopterología 9: 23-44.

de la Maza, J., de la Maza, R. G. \& de la Maza, R. 1982. Lepidopteros nuevos del Estado de Guerrero, Mexico. (Papilionoidea). Revista de la Sociedad Mexicana de Lepidopterologia 7:2-14.

de la Maza, R. 1980. Notas sobre los Papilionidae en México (Lep). VIII. Area de San Luis Potosí, S.L.P. Boletín Informativo de la Sociedad Mexicana de Lepidopterología 6: 3-14.

de la Maza, R. \& de la Maza, J. 1981. Notas sobre los Papilionidae en México (Lep) IX. Sierra de Alvarez, S. L. P. Boletín Informativo de la Sociedad Mexicana de Lepidopterología 7: 6-25.

de la Maza, R. \& de la Maza, R. G. 1978. Notas sobre la familia Papilionidae en Mexico. 1. San Nicolas Tolentino, Mex. (Lep.). Boletín Informativo de la Sociedad Mexicana de Lepidopterología 4: 3-7.

de la Maza, R., White, A. \& Ojeda, A. 1995. La horofauna higrófila de la cañada de la toma Tilzapotla, Morelos, México.(Lepidoptera-Rhopalocera). Revista de la Sociedad Mexicana de Lepidopterología 15: 1-38.

de la Maza, R. G. 1975. Notas sobre los lepidópteros de Rancho Viejo y Tepoztlán, Morelos, Mexico. Primera Parte: Papilionoidea. Revista de la Sociedad Mexicana de Lepidopterología 2:42-61.

de la Maza, R. G. \& de la Maza, J. 1993. Mariposas de Chiapas. Gobierno del Estado de Chiapas, Tuxtla Gutiérrez. 1-223 p.

de la Maza, R. G. \& de la Maza, R. 1978. Notas sobre los Papilionidae en Mexico (Lep.) IV. Area de Orizaba a Yanga, Veracruz. Boletín Informativo de la Sociedad Mexicana de Lepidopterología 4: 15-30.

- 1979. Notas sobre los Papilionidae en Mexico. V. Zona de los Tuxtlas, Veracruz. Boletín Informativo de la Sociedad Mexicana de Lepidopterología 5: 2-18.

Lamas, G. 1979. Los Dismorphiinae (Pieridae) de Mexico, America Central y las Antillas. Revista de la Sociedad Mexicana de Lepidopterologia 5: 3-37. 
Llorente, J., Garcés, A. \& Luis, A. 1986. El Paisaje Teoceleño IV. Las Mariposas de JalapaTeocelo, Veracruz. Teocelo 4: 14-37.

Llorente, J., Oñate, L., Luis, A. \& Vargas, I. 1998. Papilionidae y Pieridae de México: Distribución Geográfica e Ilustración. UNAM - CONABIO, México, D. F. 1-226 p.

Luis, A. \& Llorente, J. 1990. Mariposas en el Valle de Mexico: introduccion e historia 1. Distribucion local y estacional de los Papilionoidea de la Cañada de los Dinamos, Magdalena Contreras, D.F. Mexico. Folia Entomológica Mexicana 78: 95-198.

Luis, A., Vargas, I. \& Llorente, J. 1991. Lepidopterofauna de Oaxaca 1: distribucion y fenologia de los Papilionoidea de la Sierra de Juarez, 1 ed. Museo de Zoología, Facultad de Ciencias, UNAM, México. 1, 1-119p.

Morrone, J. J. 2001. Biogeografia de América Latina y el Caribe. M \& T - Manuales y Tesis SEA, Zaragoza, vol. 3.148 p.

Tyler, H., Brown, K. S. J. \& Wilson, K. 1994. Swallowtail butterflies of the Americas. A study in biological dynamics, dcological diversity, biosystematics, and conservation. Scientific Publishers, Gainesville. 377 p.

Vargas, I., Llorente, J. \& Luis, A. 1991. Lepidopterofauna de Guerrero I: Distribución y fenología de los Papilionoidea de la Sierra de Atoyac. Museo de Zoología, Facultad de Ciencias, UNAM, Mexico. 1-127 p.

Recibido: 2 de septiembre 2005

Aceptado: 6 de marzo 2007 
